\title{
Insulin-like growth factor II in human fetal pancreas and its co-localization with the major islet hormones: comparison with adult pancreas
}

\author{
G M Portela-Gomes ${ }^{1,3}$ and A Höög ${ }^{2}$ \\ ${ }^{1}$ Department of Genetics and Pathology, Pathology Unit, University Hospital, SE-75185 Uppsala, Sweden \\ ${ }^{2}$ Department of Tumor Pathology, Karolinska Hospital, Stockholm, Sweden \\ ${ }^{3}$ Gastroenterology Centre and Nutrition Centre, University of Lisbon, Portugal \\ (Requests for offprints should be addressed to G M Portela-Gomes, Department of Genetics and Pathology, Pathology Unit, University Hospital, \\ SE-75185 Uppsala, Sweden)
}

\begin{abstract}
Insulin-like growth factor II (IGF-II) appears to play an important role during fetal life in cell growth and differentiation in several organs, including the pancreas.

In the present study we investigated the cellular localization of IGF-II in human fetal pancreas at 16, 18 and 22 embryonic weeks and compared it with adult pancreas. Single and double immunofluorescence methods were used to study co-localization of IGF-II with the four major islet hormones - insulin, glucagon, somatostatin, pancreatic polypeptide - and with islet amyloid polypeptide (IAPP).
\end{abstract}

Distinct IGF-II immunoreactive (IR) cells were found in the endocrine, but not in the exocrine, pancreas. The intensity of IGF-II immunoreactivity was more pronounced in the fetal than in the adult pancreas. In fetal pancreas IGF-II immunoreactivity was observed in virtually all insulin-IR cells and in subsets of the glucagon, somatostatin and IAPP cells. In the adult pancreas, IGF-II immunoreactivity was found in insulin/IAPP cells only.

Our results suggest a broader effect of IGF-II in fetal endocrine pancreatic cells than in the adult.

Journal of Endocrinology (2000) 165, 245-251

\section{Introduction}

The human adult endocrine pancreas contains four major cell types: A-, B-, D- and PP-cells synthesizing glucagon, insulin, somatostatin and pancreatic polypeptide, respectively (Klöppel et al. 1998). The B-cells also co-store islet amyloid polypeptide (IAPP or amylin) (Westermark et al. 1986). During fetal development of the pancreas, endocrine cells are believed to differentiate from progenitor cells, forming clusters close to the ducts (Yamaoka \& Itakura 1999). In fetal pancreas the endocrine cells may co-store more than one of the four 'classical' islet hormones (De Krijger et al. 1992, Lukinius et al. 1992).

During fetal life, insulin-like growth factor II (IGF-II) appears to play an important role in cell growth and cell differentiation in the pancreas, as well as in other tissues and organs (Gray et al. 1987, Sara \& Hall 1990, Hedborg et al. 1994). This polypeptide may also be involved in carbohydrate metabolism (Lewitt 1994). Other family members are proinsulin/insulin, insulin-like growth factor I (IGF-I) and relaxin (Gammeltoft 1989).

In human adults, detectable levels of IGF-II have been found in many tissues including the central nervous system (Gray et al. 1987, Sara \& Hall 1990) and adrenal medulla
(Suzuki et al. 1989). This peptide has also been detected in fetal (Han et al. 1987, Bryson et al. 1989, Hill 1990, Miettinen et al. 1993), as well as in adult pancreas (Bergmann et al. 1996). In the adult pancreas, IGF-II has been found in B-cells (Höög et al. 1993, Maake \& Reinecke 1993).

The purpose of the present study was to investigate the human fetal pancreas with regard to the expression of IGF-II and its distribution in the various islet cell types.

\section{Materials and Methods}

Pancreatic tissue from three human female fetuses obtained for routine histopathological examination in connection with autopsy examination was included in the study. The gestational ages were determined to be 16,18 and 22 weeks (w). The youngest fetus was from a prostaglandin-induced abortion warranted by ultrasound findings of hygroma colli and hydrothorax, while the two older fetuses were obtained from spontaneous abortions. The fetuses measured $12 \cdot 0,19 \cdot 5$ and $25 \cdot 5 \mathrm{~cm}$, respectively (crown-rump length), and their weights were 56, 180 and $337 \mathrm{~g}$. Autopsy findings regarding the $16 \mathrm{w}$ fetus 
Table 1 Antibodies used for immunofluorescence

\begin{tabular}{|c|c|c|c|c|}
\hline $\begin{array}{l}\text { Antibody raised } \\
\text { against }\end{array}$ & Code no. & $\begin{array}{l}\text { Directed } \\
\text { against }\end{array}$ & $\begin{array}{l}\text { Working } \\
\text { dilution }\end{array}$ & Source \\
\hline $\begin{array}{l}\text { Synthetic porcine } \\
\text { glucagon }\end{array}$ & A565 & Rabbit & $1: 60$ & $\begin{array}{l}\text { DAKO Corp., } \\
\text { Santa Barbara, } \\
\text { CA, USA }\end{array}$ \\
\hline $\begin{array}{l}\text { Synthetic human } \\
\text { insulin }\end{array}$ & Ma 47 & Guinea-pig & $1: 80$ & $\begin{array}{l}\text { Dr. Per } \\
\text { Westermark, } \\
\text { Dept. Genetics } \\
\text { \& Pathology, } \\
\text { Uppsala, } \\
\text { Sweden }\end{array}$ \\
\hline $\begin{array}{l}\text { Synthetic human } \\
\text { insulin-like growth } \\
\text { factor II }\end{array}$ & 128 & Mouse & $1: 10^{*}$ & $\begin{array}{l}\text { Pharmacia \& } \\
\text { Upjohn, } \\
\text { Stockholm, } \\
\text { Sweden }\end{array}$ \\
\hline $\begin{array}{l}\text { Synthetic human } \\
\text { islet amyloid } \\
\text { polypeptide }\end{array}$ & $\begin{array}{l}\text { RAS } \\
7321\end{array}$ & Rabbit & $1: 200$ & $\begin{array}{l}\text { Peninsula } \\
\text { Laboratories, } \\
\text { Belmont, CA, } \\
\text { USA }\end{array}$ \\
\hline $\begin{array}{l}\text { Synthetic human } \\
\text { pancreatic } \\
\text { polypeptide }\end{array}$ & A619 & Rabbit & $1: 50$ & DAKO Corp. \\
\hline $\begin{array}{l}\text { Synthetic human } \\
\text { somatostatin }(1-14)\end{array}$ & A566 & Rabbit & $1: 100$ & DAKO Corp. \\
\hline
\end{tabular}

$*=20 \mu \mathrm{g} / \mathrm{ml}$.

confirmed hygroma colli and hydrothorax; a malformed right ear and horse-shoe kidney were also found; the other two fetuses displayed asphyxial hemorrhages in the lungs, due to placental ablatio. None of the mothers had a history of diabetes mellitus. Adult human pancreas was collected from three patients undergoing surgery for pancreatic adenocarcinoma. The tissue specimens were from grossly normal glandular regions and the microscopical examination revealed normal histology. This study was approved by the Medical Ethics Committee at Huddinge Hospital, Stockholm.

The pancreatic specimens obtained were fixed in $4 \%$ buffered formaldehyde solution for 18-20 h at room temperature (RT) and embedded in paraffin. Sections, $5 \mu \mathrm{m}$ thick, were cut and attached to poly-L-lysine coated glass slides. The sections were stained with hematoxylin-eosin, or immunostained to demonstrate various islet hormones (see Table 1). The streptavidin-biotin complex (ABC) technique (Hsu et al. 1981), with diamino-benzidine as chromogen, was used as a single immunostain, mainly to demonstrate the distribution of endocrine cell types in the pancreas, but also to serve as a control for the stainings mentioned below. Immunofluorescence methods were used in single or double stainings; the latter staining procedure was applied to the same section to investigate co-localization of IGF-II with the major islet hormones.

For double immunofluorescence staining, the following procedure was performed: the sections were incubated overnight with a cocktail of antibodies (one monoclonal+ one polyclonal (rabbit $\operatorname{IgG}$ or guinea-pig $\operatorname{IgG}$ )), at RT. Thereafter the sections were incubated with biotinylated goat anti-mouse $\operatorname{IgG}$ for $30 \mathrm{~min}$ at $\mathrm{RT}$ and then transferred to a mixture of fluorescein isothiocyanate (FITC)conjugated goat anti-rabbit IgG, or goat anti-guinea-pig IgG and Texas Red (TXRD)-conjugated streptavidin for $30 \mathrm{~min}$ at RT. The sections were carefully rinsed in phosphate-buffered saline (PBS) after each incubation step. Before the respective primary antibodies were applied, the sections were incubated with non-immune serum diluted 1:10 from the animal species producing the secondary antibodies.

The control stainings included omission of the primary antibody and replacement of the first layer of antibody by non-immune serum diluted 1:10 or by the diluent alone. To confirm the specificity of the IGF-II antibody, absorption tests were carried out by overnight incubation at $+4^{\circ} \mathrm{C}$, with $0 \cdot 5,2$ and 10 nmol IGF-II per $\mathrm{ml}$ diluted antibody, before application to the sections (Höög et al. 1993, 1997).

The primary antibodies are characterized in Table 1. The IGF-II antibody displayed less than 1\% crossreactivity to IGF-I (Höog et al. 1993). The labeled secondary antisera were: biotinylated goat anti-mouse $\operatorname{IgG}$ (DAKO, Glostrup, Denmark), TXRD-labeled streptavidin (Vector Laboratories, Burlingame, CA, USA), FITC-conjugated goat anti-rabbit IgG or goat antiguinea-pig IgG (Sigma, St Louis, MO, USA). The ABC kit used was from DAKO. The IGF-II antigen used in the 
absorption tests was from two different sources: Pharmacia \& Upjohn, Uppsala, Sweden, and Gropep, Adelaide, Australia.

The sections were examined using an Olympus Vanox AHBS3 fluorescence microscope (Olympus, Tokyo, Japan) equipped with filters (Olympus) giving excitation at wavelength band-widths of $475-555 \mathrm{~nm}$ for TXRD (filter no. 32821, dichroic mirror BH2-DMG) and 453$488 \mathrm{~nm}$ for FITC (no. 32822, BH2-DMIB), respectively. For simultaneous visualization of TXRD- and FITClabeled cells a double-band filter set (no. 39538, BH2DFC5) was used, giving excitation at $550-570 \mathrm{~nm}$ and 480-495 nm, respectively. Photomicrographs were taken with Fujicolor 400 film.

\section{Results}

Numerous distinct IGF-II immunoreactive (IR) cells were seen in the endocrine pancreas of the three fetuses and adults examined. The cells belonging to the exocrine parenchyma did not show any immunoreactivity. All control tests turned out as expected. The reactions of the double immunostainings did not influence one another. In the neutralization test, $0.5 \mathrm{nmol}$ gave a weak staining reaction, and was abolished when 2-10 nmol IGF-II antigen $/ \mathrm{ml}$ was used.

In the $16 \mathrm{w}$ fetus the IGF-II-IR cells were distributed in small groups, mainly connected to ducts; in the $18 \mathrm{w}$ fetus these cells also assembled in larger clusters, while in the $22 \mathrm{w}$ fetus most of the cells were concentrated into islet-like structures, with a central localization similar to that found in adult pancreas. The intensity of the IGFII-IR cells was generally stronger in the fetal than in the adult pancreas.

The immunoreactivity in IGF-II-IR cells in the $16 \mathrm{w}$ fetus varied from weak to strong, but the intensity of the IGF-II immunoreactivity was generally stronger in the two older fetuses.

IGF-II immunoreactivity was found in virtually all insulin-IR cells and vice-versa (Figs 2, 5, 8). The intracytoplasmic distributions of the IGF-II and insulin immunoreactivities were in close agreement, but the fluorescence intensity of IGF-II was usually stronger than that of insulin. In the $18 \mathrm{w}$ fetus, virtually all IGF-II cells displayed IAPP immunoreactivity and vice versa, while in the 16 and $22 \mathrm{w}$ fetuses, IGF-II was seen in only a few of the IAPP-IR cells, usually in different cytoplasmic areas (Fig. 9). IGF-II immunoreactivity appeared in a few glucagon-IR cells (Figs 1, 4, 7). In both fetuses, a few somatostatin-IR cells also displayed IGF-II immunoreactivity (Figs 3, 6, 10), appearing only in small cytoplasmic areas. IGF-II immunoreactivity was not present in any of the PP cells.

In the adult pancreas, IGF-II-IR cells displayed insulin/IAPP immunoreactivity and vice versa; the IGF-II immunoreactivity often appeared weaker than that of insulin (Fig. 11). IGF-II immunoreactivity was not observed in the glucagon-, PP- or somatostatin-IR cells.

\section{Discussion}

Several investigators have established the presence of IGF-II in adult and fetal human pancreas by using immunohistochemical, biochemical and in situ hybridization techniques (Han et al. 1987, Bryson et al. 1989, Hill 1990), whereas the present study was intended to ascertain the extent to which IGF-II might be co-localized with the major islet hormones. IGF-II has also been reported to occur in isolated islets or cell clusters (Bryson et al. 1989, Miettinen et al. 1993) or in insulin-producing cell lines (Asfari et al. 1995, Katz et al. 1997). The reason for assuming the location of IGF-II to be B-cells is the finding of IGF-II peptide and IGF-II mRNA centrally in the islets, i.e. a location known to contain insulin cells (Miettinen et al. 1993). Previous studies have confirmed that IGF-II immunoreactivity was located in B-cells in the human adult pancreas (Höög et al. 1993, Maake \& Reinecke 1993). Maake \& Reinecke (1993) were also able to demonstrate IGF-II immunoreactivity in dog and rat insulin cells.

In the present study we confirmed previous findings in adult pancreas that only insulin cells display IGF-II immunoreactivity (Höög et al. 1993, Maake \& Reinecke 1993).

The intensity of IGF-II immunoreactivity was more pronounced in the fetal than in the adult pancreas. In agreement with earlier reports showing greater expression of IGF-II mRNA in fetal than in adult tissue (Sara \& Hall 1990, Hedborg et al. 1994), our findings indicate that the fetal pancreas synthesizes more IGF-II. This suggestion is also underlined by the finding that the IGF-II peptide level declined 2 weeks after birth (Petrik et al. 1998).

Co-localization of the four major islet hormones in early fetal pancreas is well known (De Krijger et al. 1992, Lukinius et al. 1992), whereas in mature adult endocrine cells these hormones are produced and stored in separate cell types (De Krijger et al. 1992, Lukinius et al. 1992). This is the first report on the expression of IGF-II at the protein level in the major islet cell types of the human fetus. In the present study on the fetal pancreas, IGF-II-IR cells were thus found in all insulin-IR cells, as well as in some glucagon and somatostatin-IR cells.

In the oldest fetus some IAPP-IR cells did not display any IGF-II immunoreactivity. Lukinius et al. (1996) showed that a proportion of glucagon cells contained IAPP immunoreactivity in the secretory granules. This finding of co-localization of IAPP with glucagon has also been demonstrated with double immunofluorescence (PortelaGomes et al. 1999). This IAPP cell fraction may constitute the cell population not containing IGF-II. 

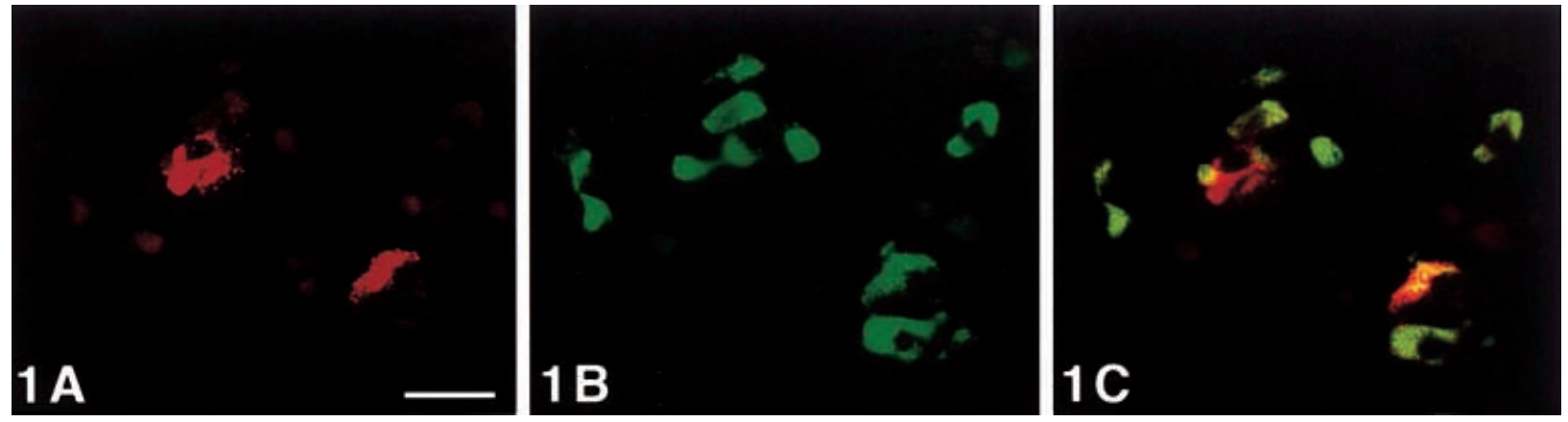

Figure 1 Fetal pancreas (16 w), double immunostained for IGF-II (Texas Red) (A) and glucagon (FITC) (B). Distinct co-localization of these two substances is shown with the double-band filter set in one cell (yellow) (C). Bar $=32 \mu \mathrm{m}$.

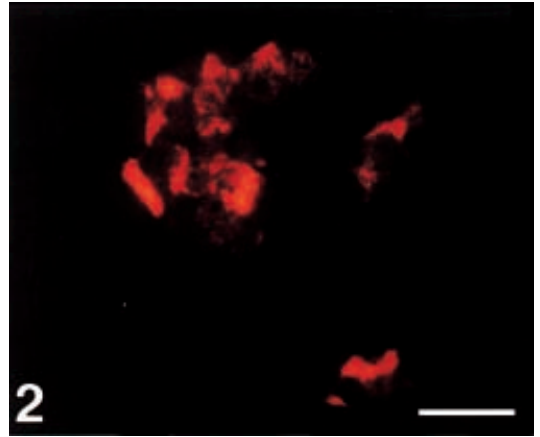

Figure 2 Fetal pancreas (16 w), double immunostained for IGF-II (Texas Red) and insulin (FITC), demonstrating varying degrees of co-localization between IGF-II and insulin (double-band filter set). The yellow colour indicates a similar amount of the two fluorescent substances, while the orange colour is indicative of a predominant IGF-II fluorescence.

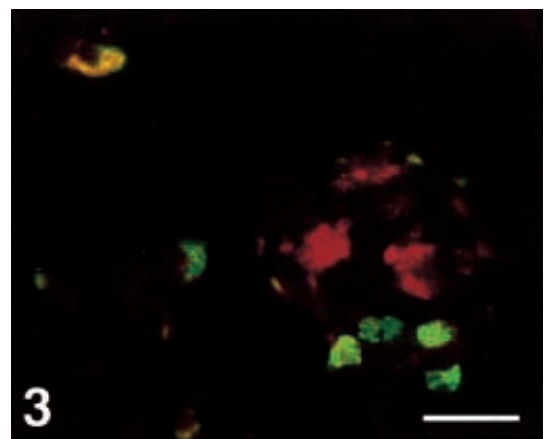

Figure 3 Fetal pancreas (16 w), double immunostained for IGF-II (Texas Red) and somatostatin (FITC), showing co-localization only in one cell (yellow). Bar $=32 \mu \mathrm{m}$.

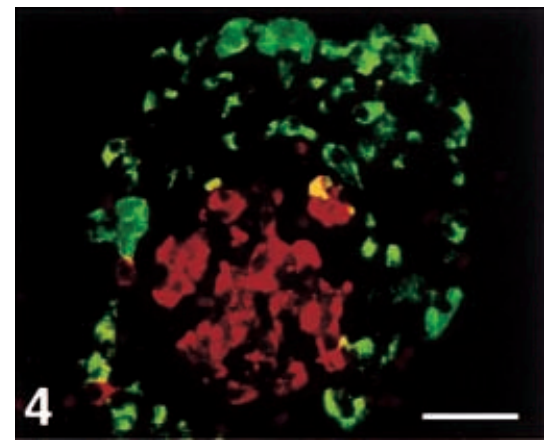

Figure 4 Fetal pancreas (18 w), double immunostained for IGF-II (Texas Red) and glucagon (FITC). In the more central part of the islet, IGF-II is seen as red. In the periphery, glucagon cells predominate. Some glucagon cells probably contain a small amount of IGF-II (yellow-green). One cell shows yellow colour, indicating a co-localization of these two peptides in more equivalent amounts. Bar $=53 \mu \mathrm{m}$.

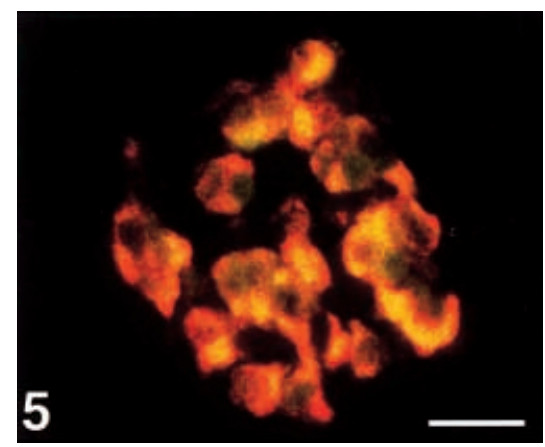

Figure 5 Fetal pancreas $(18 \mathrm{w})$, double immunostained for IGF-II (Texas Red) and insulin (FITC). Co-localization of these two peptides, illustrated by the yellow colour, is observed in all immunostained cells. Bar $=32 \mu \mathrm{m}$. 


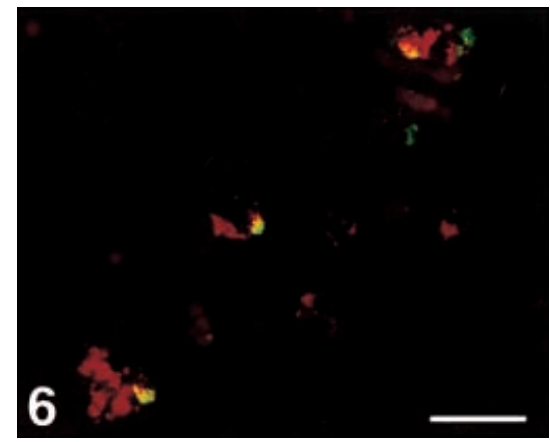

Figure 6 Fetal pancreas (18 w), double immunostained for IGF-II (Texas Red) and somatostatin (FITC), showing co-localization in some cells (yellow). Bar $=53 \mu \mathrm{m}$.

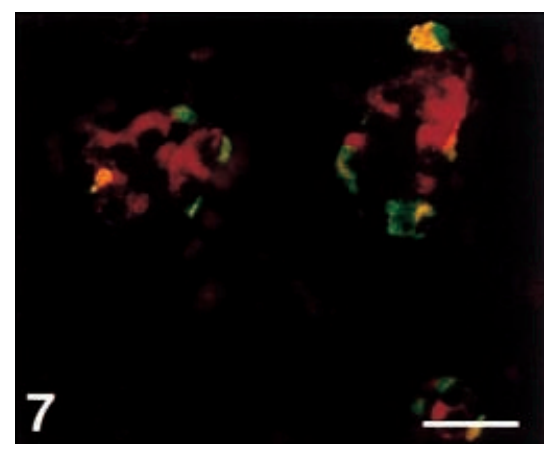

Figure 7 Fetal pancreas (22 w), double immunostained for IGF-II (Texas Red) and glucagon (FITC) demonstrating co-localization in a fraction of cells. Bar $=32 \mu \mathrm{m}$.

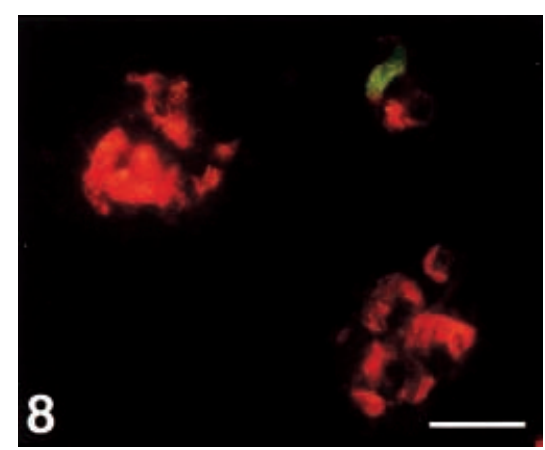

Figure 8 Fetal pancreas (22 w), double immunostained for IGF-II (Texas Red) and insulin (FITC). The orange colour indicates that IGF-II fluorescence is predominant. Bar $=32 \mu \mathrm{m}$.

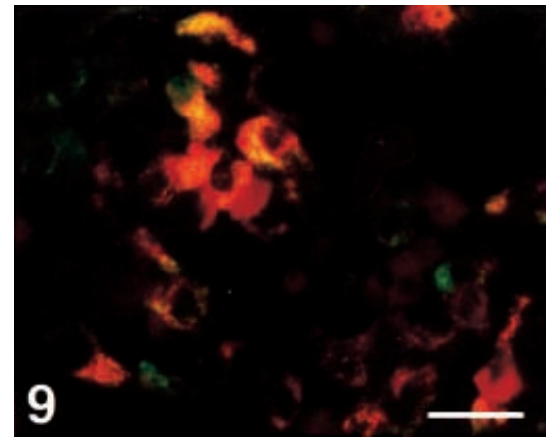

Figure 9 Fetal pancreas (22 w), double immunostained for IGF-II (Texas Red) and islet amyloid polypeptide (IAPP) (FITC). Colocalization of IGF-II and IAPP, identified by the yellow colour (double-band filter set), is present in a fraction of immunoreactive cells. In some cells, IGF-II immunoreactivity (green) and IAPP (red) appeared to occur separately. Bar $=32 \mu \mathrm{m}$.

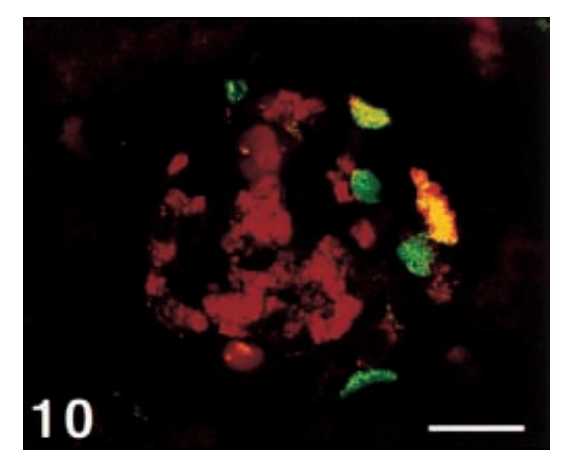

Figure 10 Fetal pancreas (22 w), double immunostained for IGF-II (Texas Red) and somatostatin (FITC), showing co-localization of these peptides in two cells (yellow colour). Bar $=32 \mu \mathrm{m}$.

Figure 11 Adult pancreas, double immunostained for IGF-II (Texas Red) (A) and insulin (FITC) (B). Insulin immunoreactivity (B) is often stronger than that of IGF-II (A). (C) With the double-band filter set, co-localization of these two peptides is visualized as yellow colour in virtually all cells. Some cells have a yellow-green colour which probably indicates that insulin fluorescence is predominant in these cells. Bar $=46 \mu \mathrm{m}$.
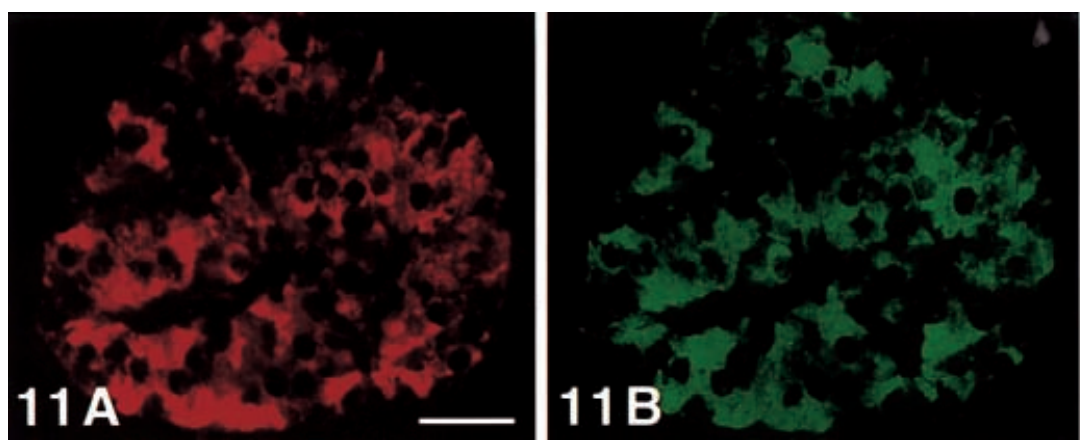

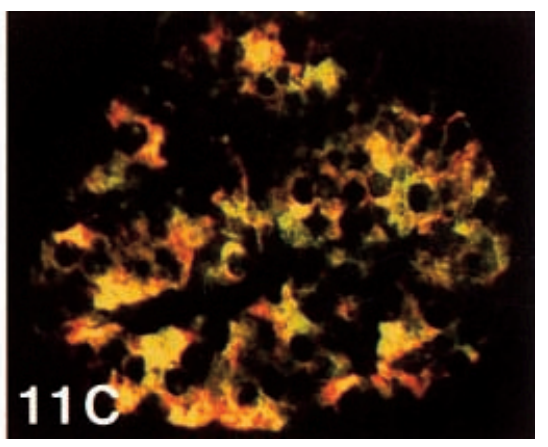

Journal of Endocrinology (2000) 165, 245-251 
Little is known about the function of IGF-II in islet cells. In a previous study in rat, using immunocytochemistry at the ultrastructural level, the IGF-II peptide has been localized to a subset of insulin containing secretory granules (Höög et al. 1997). In these animals, IGF-II peptide may play a role in the lysosomal degradation of non-released 'old' secretory granules (crinophagia) (Borg et al. 1986, Sawano et al. 1986, Nissley et al. 1991). These two findings could explain how the cell can select only older granules for degradation.

IGF-II may induce B-cell proliferation (Rabinovitch et al. 1982, Rafaeloff et al. 1993, Hill et al. 1998). Recent studies in fetal and neonatal rat pancreas suggest that endogenous IGF-II can protect islet cells from cytokineinduced apoptosis, at least in vitro. Such apoptosis is a part of the late gestational and postnatal development of the endocrine pancreas (Tornehave \& Larsson 1997, Petrik et al. 1998, Hill et al. 1999). Blocking of endogenous IGF-II with an IGF-II antibody inhibited this protective effect (Petrik et al. 1998). A decrease in apoptosis in islet cells has also been found in transgenic mice overexpressing IGF-II, giving rise to a marked islet hyperplasia (Petrik et al. 1999). Ilieva et al. (1999) have recently reported that hamster pancreatic duct epithelium contained IGF-II and that this secretion has an anti-apoptotic effect on B-cells; these results are not in line with ours but raise the question about species dependent differences in IGF-II localization.

These experimental studies indicate that IGF-II exerts a growth-regulating effect on the fetal pancreatic islets. Whether or not this applies to the human fetus is an open question. However, the present study did reveal differences between fetal and adult pancreas in the expression of IGF-II, suggesting that this peptide plays a broader and probably more important role in fetal endocrine pancreas than in the adult.

\section{Acknowledgements}

This work was supported by a grant from the Swedish Medical Research Council (No. 102), the Ernfors Family Foundation, Sweden, The Cancer Society of Stockholm (No. 98-114), and Funds of the Faculty of Medicine at Karolinska Institute. The IGF antibodies were generously donated by Mats Lake and Björn Löwenadler at Pharmacia \& Upjohn, Stockholm. We thank Professor Lars Olding for supplying the material, Professor Lars Grimelius for laboratory facilities and comments on the manuscript, Professor Henry Johansson for comments on the manuscript, and Ms Birgitta Vagnhammar for excellent technical assistance.

\section{References}

Asfari M, De W, Noel M, Holthuiz PE \& Czernichow P 1995 Insulin-like growth factor-II gene expression in a rat insulin-producing beta-cell line (INS-1) is regulated by glucose. Diabetologia 38 927-935.

Bergmann U, Funatomi H, Kornmann M, Ishiwata T, Beger HG \& Jorc M 1996 Insulin-like growth factor II activates mitogenic signaling in pancreatic cancer cells via IRS-1: in vivo evidence for an islet cancer cell axis. International Journal of Oncology 9 487-492.

Borg LAH \& Schnell-Landström A 1986 Lysosomes and pancreatic islet cell function: intracellular insulin degradation and lysosomal transformations. Diabetes Research 3 277-285.

Bryson JM, Tuch BE \& Baxter RC 1989 Production of insulin-like growth factor-II by human fetal pancreas in culture. Journal of Endocrinology 121 367-373.

De Krijger RR, Aanstoot HJ, Kranenburg G, Reinhard M, Visser WJ \& Bruining GJ 1992 The midgestational human fetal pancreas contains cells coexpressing islet hormones. Developmental Biology 153 $368-375$.

Gammeltoft S 1989 Insulin-like growth factors and insulin: gene expression, receptors and biological actions. In Peptide Hormones and Prohormones. Processing, Biological Activity and Pharmacology, pp 176-210. Ed I Martinez. Chichester: Ellis Horwood Limited.

Gray A, Tam AW, Dull TJ, Hayflick J, Pintar J, Cavenee WK, Kuofos A \& Ullrich A 1987 Tissue-specific and developmentally regulated transcription of the insulin-like growth factor 2 gene. DNA 6 283-295.

Han VKM, Hill DJ, Train AJ, Towle AC, Lauder JM, Underwood LE \& D'Ercole AJ 1987 Identification of somatomedin/insulin-like growth factor immunoreactive cells in the human fetus. Pediatric Research 22 245-49.

Hedborg F, Holmgren L, Sandstedt B \& Ohlsson R 1994 The cell type-specific IGF-2 expression during early human development correlates to the pattern of overgrowth and neoplasia in the Beckwith-Wiedemann syndrome. American Journal of Pathology 145 802-817.

Hill DJ 1990 Relative abundance and molecular size of immunoreactive insulin-like growth factors I and II in human fetal tissues. Early Human Development 21 49-58.

Hill DJ, Petrik J \& Arany E 1998 Growth factors and the regulation of fetal growth. Diabetes Care 21 B60-B69.

Hill DJ, Hogg J, Petrik J, Arany E \& Han VKM 1999 Cellular distribution and ontogeny of insulin-like growth factors (IGFs) and IGF binding protein messenger RNAs and peptides in developing rat pancreas. Journal of Endocrinology 160 305-317.

Höög A, Grimelius L, Falkmer S \& Sara VR 1993 A high-molecular IGF-2 immunoreactive peptide (pro-IGF-2?) in the insulin cells of the islets of Langerhans in pancreas of man and rat. Regulatory Peptides 47 275-283.

Höög A, Hu W, Abdel-Halim S, Falkmer S, Qing L \& Grimelius L 1997 Ultrastructural localization of insulin-like growth factor-2 (IGF-2) to the secretory granules of insulin cells. A study in normal and diabetic (GK) rats. Ultrastructural Pathology 21 457-466.

Hsu SM, Raine T \& Fanger H 1981 Use of avidin-biotin-peroxidase complex $(\mathrm{ABC})$ in immunoperoxidase techniques: a comparison between $\mathrm{ABC}$ and unlabeled (PAP) procedures. Journal of Histochemistry and Cytochemistry 29 577-580.

Ilieva A, Yuan S, Wang RN, Agapitos D, Hill DJ \& Rosenberg L 1999 Pancreatic islet cell survival following islet isolation: the role of cellular interactions in the pancreas. Journal of Endocrinology 161 357-364.

Katz LEL, Bhala A, Camron E, Nunn SE, Hintz RL \& Cohen P 1997 IGF-II, IGF-binding proteins and IGF receptors in pancreatic $\beta$-cell lines. Journal of Endocrinology 152 455-464.

Klöppel G, In't Veld P A, Komminoth P \& Heitz PU 1998 The endocrine pancreas. In Functional Endocrine Pathology, pp 415-487. Eds K Kovacs \& SL Asa. Oxford: Blackwell Scientific.

Lewitt MS 1994 Role of the insulin-like growth factors in the endocrine control of glucose homeostasis. Diabetes Research and Clinical Practical 123 3-15. 
Lukinius A, Ericsson JLE, Grimelius L \& Korsgren O 1992 Ultrastructural studies of the pancreas, with special reference to colocalization of the four major islet hormones. Developmental Biology 153 376-385.

Lukinius A, Korsgren O, Grimelius L \& Wilander E 1996 Expression of islet amyloid polypeptide in fetal and adult porcine and human pancreatic islet cells. Endocrinology 137 5319-5325.

Maake C \& Reinecke M 1993 Immunohistochemical localization of insulin-like growth factor 1 and 2 in the endocrine pancreas of rat, dog, and man, and their coexistence with classical islet hormones. Cell and Tissue Research 273 249-259.

Miettinen PJ, Otonkonski T \& Voutilainen R 1993 Insulin-like growth factor-II and transforming growth factor-alpha in developing human fetal pancreatic islets. Journal of Endocrinology 138 127-136.

Nissley P, Kiess W \& Sklar MM 1991 The insulin-like growth factor-II/manose 6-phosphate receptor. In Insulin-like Growth Factors: Molecular and Cellular Aspects, pp 123-127. Ed D LeRoith. Boca Raton, CRC Press.

Petrik J, Arany E \& Hill DJ 1998 Apoptosis in the pancreatic islet cells of the neonatal rat is associated with a reduced expression of insulin-like growth factor II that may act as a survival factor. Endocrinology $1392994-3004$.

Petrik J, Pell JM, Arany E, McDonald TJ, Dean WL, Reik W \& Hill DJ 1999 Overexpression of insulin-like growth factor-II in transgenic mice is associated with pancreatic islet cell hyperplasia. Endocrinology $1402353-2363$.

Portela-Gomes GM, Johansson H, Olding L \& Grimelius L 1999 Co-localization of neuroendocrine hormones in the human fetal pancreas. European Journal of Endocrinology 141 525-532.

Rabinovitch A, Quigley C, Russel T, Patel Y \& Mintz DH 1982 Insulin and multiplication stimulating activity (an insulin-like growth factor) stimulate islet b-cell replication in neonatal rat pancreatic monolayer cultures. Diabetes 31 160-164.

Rafaeloff R, Barlow SW, Rosenberg L \& Vinik AI 1993 IGF-II but not IGF-I is involved in islet neogenesis in adult pancreas. Diabetes $42137 \mathrm{~A}$

Sara VR \& Hall K 1990 Insulin-like growth factors and their binding proteins. Physiology Review 70 591-614.

Sawano F, Ravazzola M, Amherdt M, Perrelet A \& Orci L 1986 Horseradish peroxidase uptake and crinophagy in insulin-secreting cells. Experimental Cell Research 164 174-182.

Suzuki T, Iwafuchi M, Yanaihara C, Hatanaka H, Tao Z, Yanaihara N, Tanaka, H \& Nishikawa K 1989 IGF-II-like immunoreactivity in human tissues, neuroendocrine tumours, and PC12 cells. Diabetes Research and Clinical Practice 1 S21-S27.

Tornehave D \& Larsson L-I 1997 Presence of bcl-X1 during development of the human fetal and rat neonatal endocrine pancreas: correlation to programmed cell-death. Experimental and Clinical Endocrinology and Diabetes 105 A27.

Westermark P, Wernstedt C, Wilander E \& Sletten K 1986 A novel peptide in the calcitonin gene-related peptide family as an amyloid fibril protein in the endocrine pancreas. Biochemical and Biophysical Research Communications 140 827-831.

Yamaoka T \& Itakura M 1999 Development of pancreatic islets (Review). International Journal of Molecular Medicine 3 247261.

Received 10 September 1999 Accepted 17 December 1999 